\title{
Relationship between soil humus dissimilation, soil biological and chemical properties, and leaf litter characteristics in pure forests
}

\author{
Xiaoxi Zhang', Zengwen Liu' ${ }^{2,3 *}$, Xiaobo Liü, Xiao Liang ${ }^{1}$ \\ ${ }^{1}$ Institute of Soil and Water Conservation, Northwest A\&F University, Yangling 712100, Shaanxi, China, ${ }^{3}$ Key Laboratory of Plant Nutrition \\ and the Agri-environment in Northwest China Ministry of Agriculture, Yangling 712100, Shaanxi, China, ${ }^{2}$ College of Natural Resources and \\ Environment, Northwest A\&F University, Yangling 712100, Shaanxi, China, ${ }^{4}$ College of Forestry, Northwest A\&F University, Yangling 712100 , \\ Shaanxi, China
}

\section{A B S TR A C T}

\begin{abstract}
Soil humus dissimilation in 8 kinds of pure forests was detected and its relationship with soil biological and chemical properties and leaf litter characteristics was assessed using partial least squares regression (PLS-R). The results indicated that: The particular soil properties in pure forest rather than the litter characteristics exhibited the dominant impacts on humus accumulation and degree of humifications. High soil microbial biomass carbon (MC), alkaline $\mathrm{N}$ and available $\mathrm{P}$ contents, soil phosphatase, dehydrogenase and urease activities, and litter accumulation were associated with high humic acid accumulation, while high soil available Fe and litter Mn contents were opposite. High soil MC, alkaline N, available Zn and P contents, and dehydrogenase and phosphatase activities were in favour of fulvic acid accumulation, while the high litter Mn content were opposite. High soil MC and alkaline N contents, dehydrogenase and phosphatase activities and high litter $\mathrm{N}$ content were associated with the accumulation of humin, in contrast, increase in soil available $\mathrm{K}$ and $\mathrm{Zn}$ contents and sucrase activity hindered this process. Increases in soil available $\mathrm{K}$ content, urease and peroxidase activities and litter accumulation and $\mathrm{C} / \mathrm{P}$ ratio increased the degree of humifications of soil, while the increases in soil available Fe and Cu contents, catalase activity and litter $\mathrm{P}$ content significantly decreased it.
\end{abstract}

Keywords: Humus dissimilation; Litter characteristics; PLS-R; Soil biological and chemical properties

\section{INTRODUCTION}

The eco-environment in the Loess Plateau, China is fragile, characterized by soil erosion and deterioration of natural vegetation due to excess deforestation. The artificial pure forests play key roles in environmental protection and soil and water conservation (Liu et al., 2010). However, as the long-term selective utilization of soil nutrients by single species (Podrázský et al., 2009; Mi et al., 2015; Hansen et al., 2009) and their special environmental effects, such as single litter returning to soil and special secondary metabolite released (Mi et al., 2013; Wang et al., 2015), the pure forests generally exhibit obvious soil properties alteration (Luc et al., 2015; Mi et al., 2015; Andreetta et al., 2016), such as decreases or increases in the contents of soil organic matter and available nutrients, enzymatic activities and microbial populations (Liu et al., 2010; Mi et al., 2013). Because the formation and transformation of humus is influenced both by the litter input and soil environmental conditions (Berg and McClaugherty, 2014; Descheemaeker et al., 2009; Prescott, 2010; Trap et al., 2013; Yan, 1997; Yu et al., 2011; $\mathrm{Ni}$ et al., 2016; Li et al., 2015), the single litter properties and particular soil properties in pure forest will consequently lead to humus dissimilation — including the alterations in humus content and structure properties — in different pure forests.

As soil humus plays important roles in the soil structure formation, soil permeability and aeration maintenance, nutrient supply and soil carbon sequestration functions, it has attracted much attention in recent decades (Andreetta et al., 2011; Khaled and Fawy, 2011). The existing studies have demonstrated that the humus content and componential properties exhibited considerable specificity in different forests (Dong et al., 2015; $\mathrm{Li}$ et al., 1992). In addition, the humus properties were also

\footnotetext{
*Corresponding author:

Zengwen Liu, College of Natural Resources and Environment, Northwest A\&F University, Yangling 712100, Shaanxi, China.

E-mail: zengwenliu2003@aliyun.com
}

Received: 03 April 2016;

Revised: 23 June 2016;

Accepted: 24 June 2016;

Published Online: 14 July 2016 
significantly changed during the process of forest development and aging or when the dominant species in forests were changed (Abakumov et al., 2013; Cerli et al., 2008; Descheemaeker et al., 2009; Labaz et al., 2014; Trap et al., 2013). Noticeably, the longterm growth of pure forests sometimes will cause the losses of humus components and alterations of humus structure properties in soil (Liu et al., 2009).

However, the mechanism of humus dissimilation in different types of pure forests is far from clarified. Most of the studies tend to regard the litter quality (such as lignin, N, $\mathrm{P}, \mathrm{Mg}, \mathrm{Mn}$ contents and $\mathrm{C} / \mathrm{N}$, lignin/ $\mathrm{N}$ ratios) as the main reason causing these phenomena (Descheemaeker et al., 2009; Li et al., 1992; Trap et al., 2013), while the effects of particular/altered soil properties in pure forests on humus dissimilation still need further investigation. In addition, previous researches investigated the relationship between humus and other soil properties using simple correlation analysis methods (Ma et al., 2013; Yu et al., 2011), the results obtained still need further confirmation, because the multiple correlations among soil properties may lead to low analyzing accuracy.

In this study, 8 kinds of typical pure forest of the semihumid hilly area in the Loess plateau, China were chosen as objects. The soil humus properties were determined to assess the humus dissimilation of each pure forest. In addition, leaf litter characteristics and soil biological and chemical properties were measured, and the relationship between them and soil humus dissimilation were analyzed using partial least squares regression (PLS-R) method, aiming to provide suitable ways to prevent the harmful humus dissimilation, and to improve the stability of forest ecosystem.

\section{MATERIALS AND METHODS}

\section{Studied area}

This study was carried out in Shuanglong forest plantation, Huangling County, China. This area is a part of the temperate semi-humid loess hilly region, with an average annual temperature of $9.4^{\circ} \mathrm{C}$, an average annual precipitation of $630.9 \mathrm{~mm}$, an average relative humidity of $64 \%$, and a frost-free period of 150 days. The dominate tree species are Pinus tabulaeformis, Platycladus orientalis, Larix principisrupprechtii, Pinus armandii, Robinia psendoacacia, Populus simonii, Quercus liaotungensis and Betula platyphylla, and the main undergrowth plants are Lonicera standishii, Elaeagnus umbellate, Periploca sepium, Sophora davidii, Carex rigescens, Agropyron cristatum, Lespedeza formosa, Urena lobata and Aremisia spp. The overall coverage of the undergrowth shrub and grasses is less than $15 \%$ in each pure forest.

\section{Sampling of soil and litter}

In the study area, 8 kinds of typical pure forest with similar site conditions (shaded and half shaded slopes at the middle-upper parts of loess ridge, with slopes within $22-30^{\circ}$ ) were chosen (Table 1). Three standard plots $(20 \times 20 \mathrm{~m})$ were established within each pure forest, and every tree individual was counted and measured to obtain the the stand structure. Five quadrats with a size of $1 \times 1 \mathrm{~m}$ were subsequently established within each standard plot, and all humus layer (0-10 cm depth) soil from the 5 quadrats was gathered and mixed uniformly after removing roots and stones. Humus soil from the same standard plot was then homogenized again and $3 \mathrm{~kg}$ soil was sampled from the mixture with quarter method. That is, a twicemixed soil sample was gathered from each standard plot, and totally 3 samples were collected from each forest. Simultaneously, leaf litter from quadrats in each forest was collected, rapidly rinsed and oven dried at $65^{\circ} \mathrm{C}$, and then weighed for calculating the litter accumulation. The current-year litter was used for substrate quality determinations (Table 1).

\section{Determination of the soil and litter properties}

The following methods suggested by Bao (2000) were used for the determinations of soil properties: Humus contents (including humic acid-HA, fulvic acid-FA and humin-HM) were measured by tetrasodium pyrophosphate extraction- potassium dichromate oxidation method,

Table 1: Introductions for the tested forests ${ }^{a}$

\begin{tabular}{|c|c|c|c|c|c|c|c|c|c|c|}
\hline \multirow[t]{2}{*}{ Species } & \multicolumn{5}{|c|}{ Properties of pure forests } & \multicolumn{5}{|c|}{ Litter substrate quality } \\
\hline & $\begin{array}{l}\text { Age } \\
(\mathrm{Yr})\end{array}$ & $\begin{array}{l}\text { Average DBH } \\
(\mathrm{cm})\end{array}$ & $\begin{array}{c}\text { Average } \\
\text { height }(m)\end{array}$ & $\begin{array}{c}\text { Density } \\
\left(\text { plants } / \mathrm{hm}^{2}\right)\end{array}$ & $\begin{array}{c}\text { Litter } \\
\text { accumulation } \\
\left(\mathrm{t} / \mathrm{hm}^{2}\right)\end{array}$ & $\mathrm{C} / \mathrm{N}$ & C/P & $N(g / k g)$ & $P(g / k g)$ & $\operatorname{Mn}(\mathrm{mg} / \mathrm{kg})$ \\
\hline P. $t$. & 30 & 12.95 & 7.3 & 3655 & 4.08 & $31.04 a$ & $536.51 a$ & $9.16 \mathrm{~d}$ & $0.53 f$ & $41.68 \mathrm{~g}$ \\
\hline L. $p$. & 29 & 21.26 & 16.8 & 595 & 1.65 & $12.46 \mathrm{c}$ & $95.58 d$ & $20.55 c$ & $2.68 \mathrm{a}$ & $261.14 b$ \\
\hline P. o. & 31 & 12.19 & 6.7 & 2500 & 1.85 & $8.99 d$ & $125.69 c$ & $28.94 a$ & $2.07 c$ & $30.59 \mathrm{~h}$ \\
\hline P. a. & 28 & 9.62 & 7.9 & 2512 & 3.56 & $21.03 b$ & 213.37b & $12.58 \mathrm{~d}$ & $1.24 \mathrm{e}$ & $148.18 f$ \\
\hline R. $p$. & 27 & 16.24 & 11.5 & 1700 & 4.65 & $9.51 d$ & $217.42 b$ & $24.92 a b c$ & $1.09 \mathrm{e}$ & $210.26 e$ \\
\hline P. s. & 24 & 18.34 & 19.7 & 1657 & 0.65 & $8.71 d$ & $138.91 \mathrm{c}$ & $23.93 b c$ & $1.5 d$ & $220.35 d$ \\
\hline B. $p$. & 32 & 11.92 & 9.8 & 4359 & 1.25 & $9.23 d$ & $104.49 d$ & 28.19ab & $2.49 b$ & $270.56 a$ \\
\hline Q.I. & 31 & 14.26 & 11.7 & 3597 & 3.45 & $11.86 \mathrm{c}$ & $104.46 d$ & $20.96 c$ & $2.38 b$ & $230.27 c$ \\
\hline
\end{tabular}

a: P. t.: Pinus tabuliformis, L. p.: Larix principis-rupprechtii, P. o.: Platycladus orientalis, P. a.: Pinus armandii, R. p.: Robinia pseudoacacia, P. s.: Populus simonii, B. p.: Betula platyphylla, Q. I.: Quercus liaotungensis. Different letters in the same column indicated significant differences between soils, the same below 
available $\mathrm{N}$ (ALN) content by alkaline hydrolysis diffusion method, available P (AP) by phosphomolybdenum blue colorimetry using a UV-VIS spectrophotometer (Shimadzu Corporation, Japan), available K (AK) by a flame photometer (BMB Technologies UK LTD.), available $\mathrm{Cu}$, $\mathrm{Zn}, \mathrm{Fe}, \mathrm{Mn}$ (ACu, AZn, AFe and AMn) by DTPA extraction method using an atomic absorption spectrophotometer (Hitachi, Tokyo, Japan).

Enzyme activities were measured by the methods suggested by Guan (1986): Urease (Ure) was determined by the indophenol blue colorimetry, sucrase (Suc) by hyposulphite titrimetry, peroxidase (Per) by potassium permanganate titrimetry, dehydrogenases (Deh) by triphenyltetrazolium chloride colorimetry, phosphatase (Pho) by disodium phenyl phosphate colorimetry and protease (Pro) by the ninhydrin colorimetry. Microbial biomass carbon (MC) was measured by chloroform fumigation method.

Carbon content of litter samples was measured by potassium dichromate oxidation method, $\mathrm{N}(\mathrm{LN})$ by a continuous flow analytical system (Auto Analyzer 3, Bran Luebbe, Germany), P, and Mn (LP and LMn) were measured by the same instruments as soil (Bao, 2000).

\section{Data processing}

Data were analyzed by IBM SPSS 19.0 using one-way analysis of variance to assess the differences between soil and litter samples, and the least significant difference method was employed in post hoc analysis $(\mathrm{P}<0.05)$. The relationships between soil biological and chemical properties/litter characteristics and humus properties were analyzed by SIMCA-P 11.5 using partial least squares regression (PLS-R) method.

\section{RESULTS}

Dissimilation of humus properties of 8 pure forests Humus soil from 8 mature forests showed significant differences (Fig. 1) in humus component content and degree of humifications ( $Q_{p}=$ humic acid/humus). In which, humus soil from $P$. orientalis and R. pseudoacacia forests had the highest humic acid (HA) content (3.93-4.21 $\mathrm{g} \mathrm{kg}^{-1}$ ), followed by Q. liaotungensis, P. tabuliformis, L. principisrupprechtii and B. platyphylla forests $\left(2.67-3.73 \mathrm{~g} \mathrm{~kg}^{-1}\right)$, while humus soil from $P$. armandii and $P$. simonii forests showed the lowest HA content (1.91-2.29 $\left.\mathrm{g} \mathrm{kg}^{-1}\right)$. Humus soil from $P$. orientalis forest had the highest fulvic acid (FA) content $\left(8.08 \mathrm{~g} \mathrm{~kg}^{-1}\right)$, followed by R. pseudoacacia, Q. liaotungensis, L. principis-rupprechtii, B. platyphylla, P. tabuliformis and P. armandii forests $\left(4.17-5.20 \mathrm{~g} \mathrm{~kg}^{-1}\right)$, while humus soil of $P$. simonii showed the lowest FA content $\left(2.86 \mathrm{~g} \mathrm{~kg}^{-1}\right)$. Humus soil from P. orientalis, B. platyphylla and Q. liaotungensis forests showed the highest humin (HM) content (12.46-13.38 $\left.\mathrm{g} \mathrm{kg}^{-1}\right)$, followed by R. pseudoacacia, P. tabuliformis and $P$. armandii forests $\left(8.80-9.56 \mathrm{~g} \mathrm{~kg}^{-1}\right)$, while soil from L. principis-rupprechtii and P. simonii forests showed the lowest HA content $\left(6.17-7.08 \mathrm{~g} \mathrm{~kg}^{-1}\right)$.

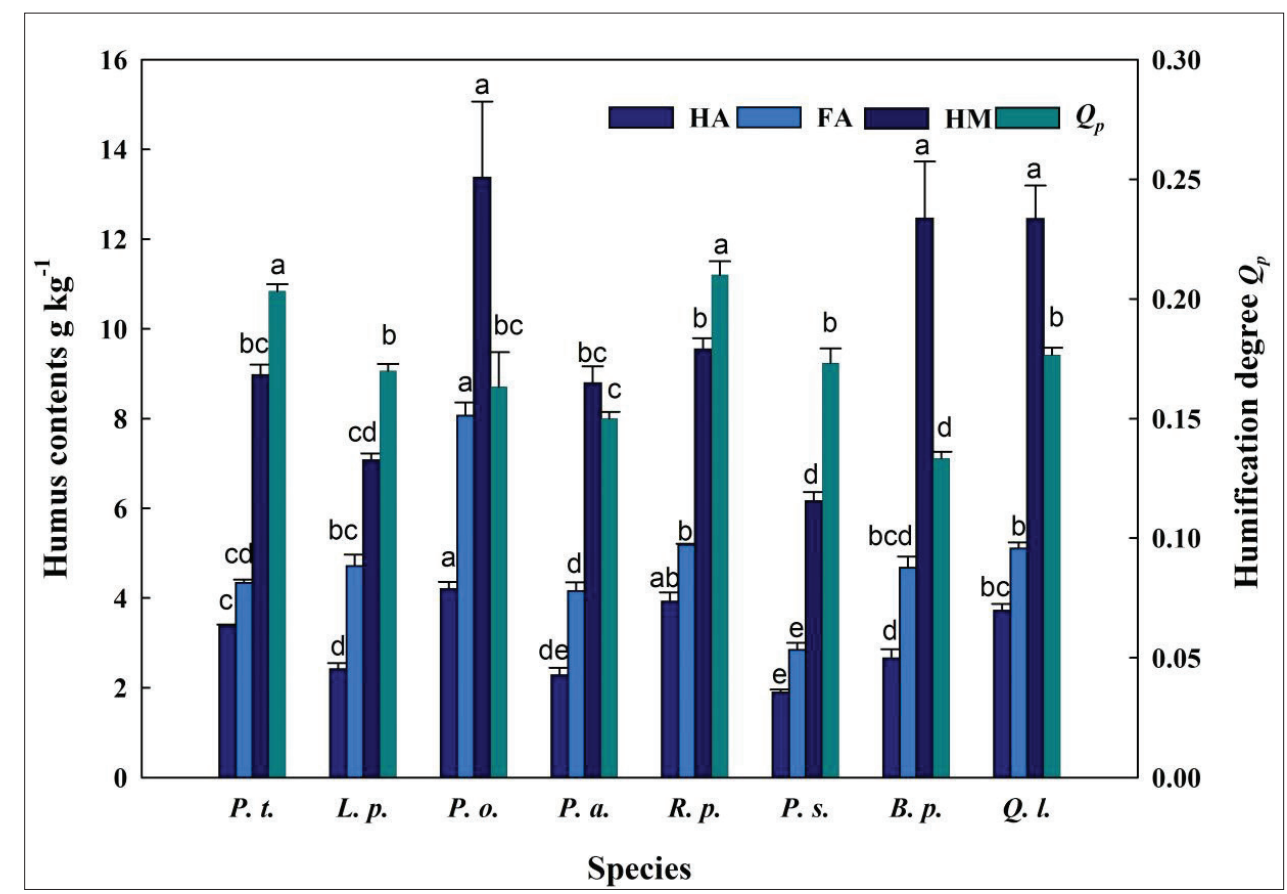

Fig 1. Humus properties of soil from 8 kinds of pure forests. P. t.: Pinus tabuliformis, L. p.: Larix principis-rupprechtii, P. o.: Platycladus orientalis, P. a.: Pinus armandii, R. p.: Robinia pseudoacacia, P. s.: Populus simonii, B. p.: Betula platyphylla, Q. I.: Quercus liaotungensis, HA-Humic acid, FA-Fulvic acid, HM-Humin, $Q_{p}$-Humification degree. Different letters indicated significant differences between soils, the same below. 
The result indicated that the $Q_{p}$ of humus soil from P. tabuliformis and R. psendoacacia forests was the highest in the tested 8 forests, followed by L. principis-rupprechtii, $P$. simonii, $Q$. liaotungensis, $P$. orientalis and $P$. armandii, while humus soil from B. platyphylla forest exhibited the lowest $Q_{p}$ value. As HA exhibit higher aromatization than other components in humus, these results indicated that the humus formed in P. tabuliformis and R. pseudoacacia forests had better humus stability.

Soil chemical and biological properties in $\mathbf{8}$ pure forests Significant differences were observed in nutrient contents in the soil from 8 pure forests (Table 2). In which, $P$. orientalis forest soil had the highest alkaline $\mathrm{N}$ contents, while $P$. tabuliformis and L. principis-rupprechtii forests soil showed the lowest. P. orientalis forest soil exhibited the highest available $\mathrm{P}$ content, while $L$. principis-rupprecbtii forest soil had the lowest. R. pseudoacacia forest soil was the richest in available $\mathrm{K}$ contents, while $P$. armandii forest soil was the poorest. The highest available $\mathrm{Cu}$ content was observed in L. principis-rupprecbtii forest and the lowest was observed in P. armandii, P. tabuliformis and R. psendoacacia forests. P. orientalis forest soil showed the highest available $Z n$ content, while the $P$. armandii forest soil showed the lowest. Q. liaotungensis, L. principis-rupprecbtii and B. platyphylla forests soil exhibited the highest available Fe contents, while the R. psendoacacia forest showed the lowest. L. principis-rupprechtii forest was the richest in available Mn contents, while $P$. armandii and R. pseudoacacia forests were the poorest.
In different forest soils, significant differences were also observed in enzyme activities and microbial biomass carbon contents (Table 3). Among them, R. pseudoacacia forest soil showed the highest urease activity, while $P$. armandii forest showed the lowest. L. principis-rupprechtii forest soil exhibited the highest sucrase activity, while B. platyphylla forest showed the lowest. L. principis-rupprechtii and R. pseudoacacia forests soil showed the highest peroxidase activity, while soil from other forests showed the lowest. P. orientalis forest soil showed the highest dehydrogenase activity, while L. principis-rupprechtii forest soil showed the lowest. P. orientalis forest soil showed the highest phosphatase activity, while L. principis-rupprecbtii and B. platyphylla showed the lowest. B. platyphylla forest soil showed the highest protease activity, while $P$. armandii showed the lowest. The microbial biomass carbon content was the richest in P. orientalis forest soil, while P. simonii forest soil was the lowest.

The relationship between humus dissimilation and soil bio-chemical properties/litter characteristics

Considering the multiple correlations within litter/soil properties, partial least squares regression was employed for assessing the relationships between humus properties (Fig. 1) with litter characteristics (Table 1) and soil biological and chemical properties (Tables 2 and 3). Litter and soil properties were defined as independent variables, while the humus properties were defined as dependent variables. The sign ( + and -$)$ of coefficient of the independent variables in obtained regression models (Equations 1-4), which indicated the trend of each parameter. All models

Table 2: Contents of nutrient element in soil of pure forests

\begin{tabular}{|c|c|c|c|c|c|c|c|}
\hline Species & $\begin{array}{c}\text { Alkaline } N \\
(\mathrm{~g} / \mathrm{kg})\end{array}$ & $\begin{array}{c}\text { Available P } \\
(\mathrm{g} / \mathrm{kg})\end{array}$ & $\begin{array}{c}\text { Available K } \\
(\mathrm{g} / \mathrm{kg})\end{array}$ & $\begin{array}{c}\text { Available Cu } \\
(\mathrm{mg} / \mathrm{kg})\end{array}$ & $\begin{array}{c}\text { Available Zn } \\
(\mathrm{mg} / \mathrm{kg})\end{array}$ & $\begin{array}{c}\text { Available Fe } \\
(\mathrm{mg} / \mathrm{kg})\end{array}$ & $\begin{array}{c}\begin{array}{c}\text { Available Mn } \\
(\mathrm{mg} / \mathrm{kg})\end{array} \\
\end{array}$ \\
\hline P. tabuliformis & $93.38 f$ & $6.61 d$ & $129.86 b$ & $0.41 \mathrm{e}$ & $5.42 d$ & $9.64 \mathrm{c}$ & $11.47 \mathrm{c}$ \\
\hline L. principis-rupprechtii & $95.58 \mathrm{ef}$ & $4.51 f$ & $115.12 c$ & $1.40 \mathrm{a}$ & $7.16 \mathrm{~b}$ & $14.66 \mathrm{ab}$ & $19.03 a$ \\
\hline P. orientalis & $171.02 a$ & $9.24 a$ & $79.92 d$ & $0.89 c$ & $10.25 a$ & $9.14 \mathrm{~cd}$ & $17.10 \mathrm{~b}$ \\
\hline P. armandii & $104.65 \mathrm{de}$ & $6.7 \mathrm{~cd}$ & $50.76 f$ & 0.40 ef & $3.60 f$ & $13.33 b$ & $3.73 \mathrm{e}$ \\
\hline R. pseudoacacia & $123.43 c$ & $7.67 \mathrm{~b}$ & $158.93 a$ & $0.30 f$ & $5.43 d$ & $6.51 d$ & $4.25 \mathrm{e}$ \\
\hline P. simonii & $108.14 d$ & $7.4 \mathrm{bc}$ & $127.55 b$ & $0.70 d$ & $6.25 c$ & $13.13 b$ & $8.70 d$ \\
\hline B. platyphylla & $118.07 c$ & $5.36 \mathrm{e}$ & $62.11 \mathrm{e}$ & $1.01 b$ & $6.78 b c$ & $14.28 a b$ & $8.38 d$ \\
\hline Q. liaotungensis & $152.41 b$ & $6.00 \mathrm{de}$ & $86.70 d$ & $0.87 c$ & $4.48 \mathrm{e}$ & $16.87 a$ & $13.28 c$ \\
\hline
\end{tabular}

Table 3: Biological properties of soil of pure forests

\begin{tabular}{|c|c|c|c|c|c|c|c|c|}
\hline \multirow[t]{2}{*}{ Species } & \multicolumn{7}{|c|}{ Enzyme activities } & \multirow{2}{*}{$\begin{array}{c}\text { Microbial } \\
\text { biomass carbon } \\
(\mathrm{mg} / \mathrm{kg})\end{array}$} \\
\hline & $\begin{array}{l}\text { Urease } \\
(\mathrm{mg} / \mathrm{kg})\end{array}$ & $\begin{array}{c}\text { Sucrase } \\
(\mathrm{ml} / \mathrm{g})\end{array}$ & $\begin{array}{c}\text { Catalase } \\
(\mathrm{ml} / \mathrm{g})\end{array}$ & $\begin{array}{c}\text { Peroxidase } \\
(\mathrm{ml} / \mathrm{kg})\end{array}$ & $\begin{array}{c}\text { Dehydrogenase } \\
(\mu \mathrm{g} / \mathrm{g})\end{array}$ & $\begin{array}{c}\text { Phosphatase } \\
(\mathrm{mg} / \mathrm{kg})\end{array}$ & $\begin{array}{c}\text { Protease } \\
(\mathrm{mg} / \mathrm{g})\end{array}$ & \\
\hline P. tabuliformis & $19.37 \mathrm{bc}$ & $1.70 \mathrm{e}$ & $2.25 a$ & $6.64 b$ & $108.14 \mathrm{bc}$ & $0.40 b$ & $0.16 \mathrm{bc}$ & $63.67 c$ \\
\hline L. principis-rupprechtii & $19.91 b$ & $4.59 a$ & $2.28 \mathrm{a}$ & $8.96 a$ & $83.15 \mathrm{e}$ & $0.22 e$ & $0.21 a b$ & $56.22 d$ \\
\hline P. orientalis & $20.52 b$ & $3.34 b$ & $2.29 a$ & $6.47 \mathrm{~b}$ & $143.18 a$ & $0.56 a$ & $0.17 \mathrm{bc}$ & $88.27 a$ \\
\hline P. armandii & $11.42 d$ & 2.06de & $2.27 a$ & $5.97 \mathrm{~b}$ & $101.37 \mathrm{bc}$ & $0.26 \mathrm{de}$ & $0.10 d$ & $56.00 d$ \\
\hline R. pseudoacacia & $35.34 a$ & $2.84 \mathrm{c}$ & $2.2 a$ & $8.47 a$ & $111.18 b$ & $0.32 c$ & $0.15 \mathrm{~cd}$ & $60.38 \mathrm{~cd}$ \\
\hline P. simonii & $14.99 \mathrm{~cd}$ & $2.12 d$ & $2.29 a$ & $6.73 b$ & $99.21 \mathrm{~cd}$ & $0.29 \mathrm{~cd}$ & $0.15 \mathrm{~cd}$ & $38.25 e$ \\
\hline B. platyphylla & $18.76 b c$ & $0.50 f$ & $2.25 a$ & $6.47 \mathrm{~b}$ & $89.46 \mathrm{de}$ & $0.21 e$ & $0.24 a$ & $66.06 c$ \\
\hline Q. liaotungensis & $22.9 b$ & $2.24 d$ & $2.26 \mathrm{a}$ & $6.97 b$ & $100.67 \mathrm{c}$ & $0.33 c$ & $0.15 \mathrm{~cd}$ & $73.82 b$ \\
\hline
\end{tabular}


strength were tested by the values $R^{2} Y$ (the fraction of the variation of $Y$ explained by the model) and $Q^{2}$ (the fraction of the variation of $Y$ that can be predicted by the model according to the cross-validation), values of $R^{2} Y$ and $Q^{2}$ close to 1.0 indicate an excellent model, and all models' significance were confirmed. In addition, the Variable Importance of Projection (VIP) value was used for the assessment of the relative influence of each parameter in the models. A VIP $>1$ indicated the parameter was the most relevant and significant for explaining the dependent variables.

The results revealed that (Equations 1-4, Fig. 2): Higher soil microbial biomass carbon, alkaline $\mathrm{N}$ and available P contents, higher soil phosphatase, dehydrogenase and urease activities, and higher litter accumulation were to the benefit of humic acid (HA) accumulation, while the higher soil available Fe and litter Mn contents were adverse to HA accumulation. Higher soil microbial biomass carbon, alkaline $\mathrm{N}$, available $\mathrm{Zn}$ and $\mathrm{P}$ contents, and higher soil dehydrogenase and phosphatase activities were in favor of the accumulation of fulvic acid (FA), while the increase in litter Mn content exhibited relative significant negative effects on this process. Increases in soil microbial biomass carbon and alkaline $\mathrm{N}$ contents, soil dehydrogenase and phosphatase activities and litter $\mathrm{N}$ content could accelerate the accumulation of humin (HM), in contrast, increase in soil available $\mathrm{K}$ and $\mathrm{Zn}$ contents and soil sucrase activity would hinder this process. Increases in soil available $\mathrm{K}$ content and urease and peroxidase activities and higher litter accumulation and $\mathrm{C} / \mathrm{P}$ ratio would promote the humification processes in soil, while the increases in soil available $\mathrm{Fe}$ and $\mathrm{Cu}$ contents, soil catalase activity and litter P content exhibited considerable inhibitory effects.

$$
\begin{aligned}
\mathrm{HA}= & 3.5964+0.2187 \mathrm{LA}+0.0222 \mathrm{CNr}+0.0457 \mathrm{CPr}+0.0198 \\
& \mathrm{LN}+0.0459 \mathrm{LP}-0.0563 \mathrm{LMn}+0.2105 \mathrm{ALN}+ \\
& 0.0057 \mathrm{AP}+0.0163 \mathrm{AK}-0.0103 \mathrm{ACu}-0.0070 \mathrm{AZn}- \\
& 0.0295 \mathrm{AFe}+0.0892 \mathrm{AMn}+0.2347 \mathrm{Ure}-0.0074 \text { Suc- } \\
& 0.1817 \mathrm{Cat}+0.0505 \text { Per+0.1070 Deh+ } \\
& 0.1413 \mathrm{Pho}+0.0387 \text { Pro+0.2901 MC }
\end{aligned}
$$

$$
\begin{aligned}
\mathrm{FA}= & 3.3109+0.1320 \mathrm{LA}+0.0132 \mathrm{CNr}-0.0229 \\
& \mathrm{CPr}+0.0359 \mathrm{LN}+0.0869 \mathrm{LP}-0.1102 \mathrm{LMn} \\
& +0.1607 \mathrm{ALN}+0.0296 \mathrm{AP}-0.1319 \mathrm{AK}+0.0477 \\
& \mathrm{ACu}+0.1034 \mathrm{AZn}-0.0767 \mathrm{AFe}+0.0933 \\
& \mathrm{AMn}+0.1039 \text { Ure }+0.0933 \mathrm{Suc}-0.0724 \mathrm{Cat} \\
& +0.0300 \text { Per+0.1421 Deh+0.1247 Pho } \\
& +0.0496 \text { Pro }+0.2966 \mathrm{MC}
\end{aligned}
$$

\footnotetext{
$\mathrm{HM}=3.7165+0.1365 \mathrm{LA}-0.0084 \mathrm{CNr}-0.0272$ CPr+0.0878 LN+0.1327 LP-0.0178 LMn +0.2506 ALN-0.0365 AP-0.2316 AK+0.0175
}

ACu-0.0046 AZn+0.0618 AFe-0.0018

$\mathrm{AMn}+0.1143$ Ure-0.2187 Suc-0.1651 Cat-0.1418

Per+0.0774 Deh+0.0729 Pho+0.1285 Pro

$+0.3626 \mathrm{MC}$

$$
\begin{aligned}
Q_{p}= & 6.9196+0.1186 \mathrm{LA}+0.0552 \mathrm{CNr}+0.1096 \mathrm{CPr}-0.0554 \\
& \text { LN-0.1170 LP-0.0516 LMn-0.0237 ALN } \\
& +0.0503 \mathrm{AP}+0.1724 \text { AK-0.0932 ACu- } 0.0309 \\
& \text { AZn-0.1160 AFe-0.0085 AMn+0.1248 Ure } \\
& +0.0569 \text { Suc-0.0990 Cat+0.0923 Per+0.0421 } \\
& \text { Deh+0.0584 Pho-0.0597 Pro-0.0201 MC }
\end{aligned}
$$

\section{DISCUSSION}

The relationship between humus dissimilation with other soil properties and litter characteristics

Our results demonstrated that there were considerable humus dissimilation phenomena in the tested pure forests, which was similar to the findings of Li et al. (1992), He (2002), Dong et al. (2015), Pshenichnikov and Pshenichnikova (2015) and Ni et al. (2016). In addition, the results of PLS-R revealed that both litter characteristics and particular soil biological and chemical properties contributed to the dissimilation of humus, however, it was the soil properties rather than the litter characteristics which showed the dominant impacts on humus accumulation and humification processes. This result was in contrast with the findings of Descheemaeker et al. (2009) and Trap et al. (2013). We hypothesized that litter mainly influence the humus properties by changing soil biological and chemical properties, thus its relations with humus were hard to be directly observed.

Specifically, the results of PLS-R indicated that high microorganism biomass carbon contents were in favor of the accumulations of HA, FA and HM. The humification processes were controlled by microbial activities (Berg and McClaugherty, 2014; Schaeffer et al., 2015): the organic matters (such as lignin, cellulose, protein, phenolic and other substances) entered in soil might be decomposed, transformed and re-compounded to form humus, thus the increases in microbial biomass accelerated the overall humus formation. Certainly, as the diversity of microorganisms, the increases in microbial biomass might also cause the dissimilation of humus components. As examples, the white rot fungi tend to completely decompose the organic matters, while brown-rot fungi can promote the humification processes (Berg and McClaugherty, 2014). Trichoderma is in favor of the formation of HA and in favor of the increase of the humification degree, while the activity of Streptomyces is more beneficial to form FA (Guan and Dou, 2006; Li et al., 2015). However, Cortinarius spp. would lead to the oxidation of humus materials (Bödeker et al., 2014). 


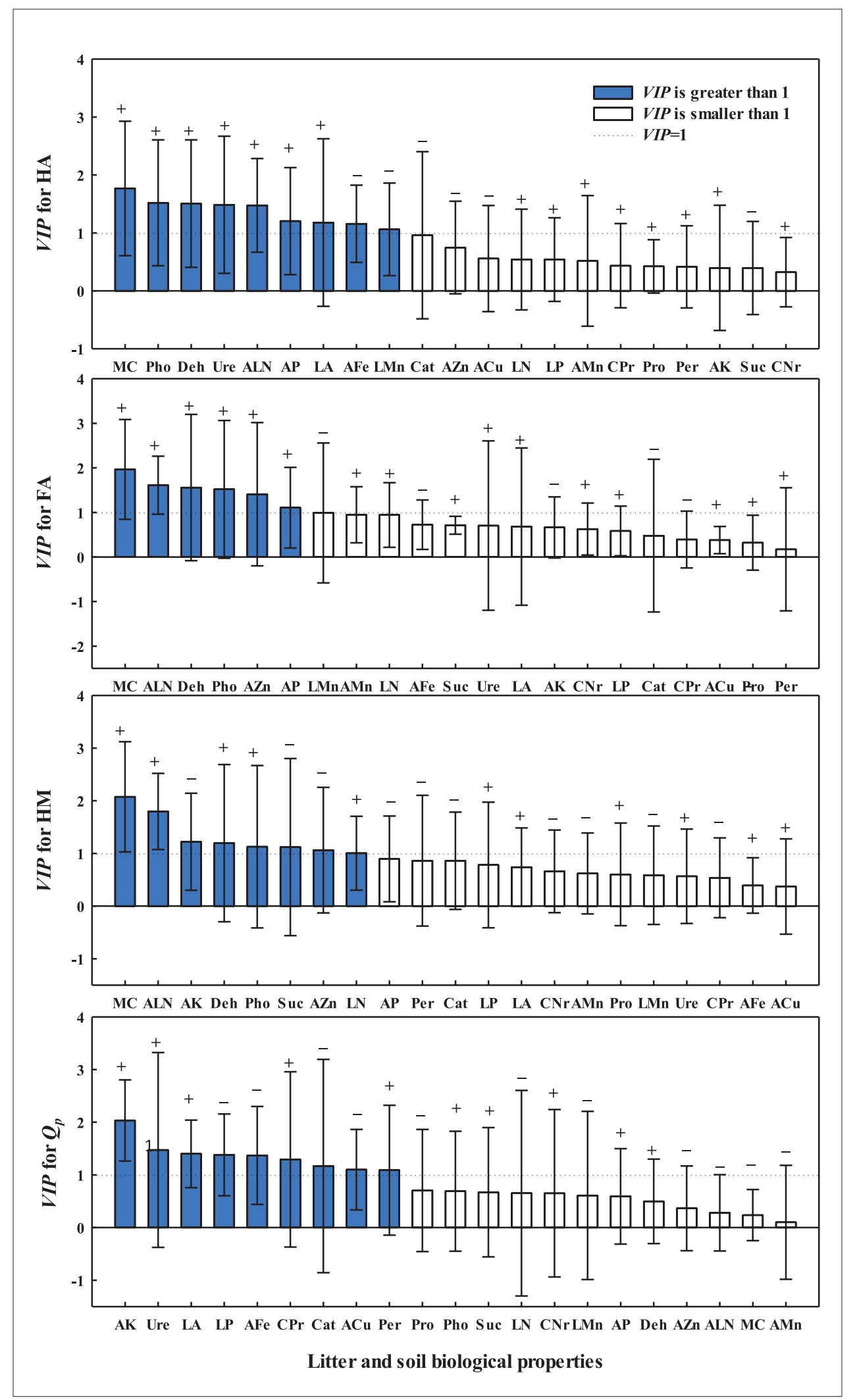

Fig 2. Variable importance in projection (VIP) values of litter and soil properties for humus properties. Soil vailable nutrients contents: ALNAlkaline N, AP-Available P, AK-Available K, ACu-Available Cu, AZn-Available Zn, AFe-Available Fe, AMn-Available Mn. Soil enzyme activities: Ure-urease, Suc-sucrase, Cat-catalase, Per-peroxidase, Deh-dehydrogenase, Pho- Phosphatase, Pro-protease. Microbial property: MC-Microbial biomass carbon. Litter properties: LA-Litter accumulation, CNr-Ratio of C and N, CPr-Ratio of C and P, LN-N content of litter, LP-P content of litter, LMn-Mn content of litter. The sign (+ and -) indicated the trend of indicators. 
For soil enzymes, high activities of phosphatase and dehydrogenase were benefit for the accumulations of all three kinds of humus components, while high urease activity could lead to a higher accumulation of HA and the increase in degree of humifications, which was agreed with the findings of Yu et al. (2011) while was contrary to the findings of Yan (1997). These indicated that the $\mathrm{N}$ and $\mathrm{P}$ supplements might be the main limitations for humification in the tested area, thus the increases of phosphatase and urease could promote the humus accumulation and humification processes. Dehydrogenase was closely associated with the microbial activity and the decomposition of soil organic matters, while peroxidase could catalyze the oxidation of phenolic matters (Yan, 1997; Bödeker et al., 2014), the increases in these two kinds of enzyme would consequently accelerate the decomposition (not completely decomposition) and transformation of plant litter and other organic residues, and thus provide sufficient precussor substances for humus. In contrast, the increase of sucrase activity could hinder the accumulation of HM, this revealed that the micro-molecule carbohydrate might participate in the formation of $\mathrm{HM}$, which is contrary to the findings of Paul (2002). Moreover, the results demonstrated that high catalase activity could decrease the degree of humifications of humus, that might be resulted from its ability of catalyzing the rapidly decomposition of $\mathrm{H}_{2} \mathrm{O}_{2}$ (which plays key roles in the transformation of lignin and the other substances, Yan, 1997; Bödeker et al., 2014), thus hinder the humification processes.

For soil nutrient elements, the results of PLS-R revealed that the high available $\mathrm{N}$ and $\mathrm{P}$ contents in soils also promoted the accumulation of humus components, which was in line with the findings of Prescott (2010), Dang et al. (2012) and $\mathrm{Ma}$ et al. (2013). Sufficient N and P supplements could accelerate the microbial reproduction and thus promote the humus accumulations. In addition, $\mathrm{N}$ could combine with lignin and form recalcitrant materials and inhibit the lignin-decomposing enzyme activity (Hassett et al., 2009; Lauber et al., 2009; Tu et al., 2014; Rinkes et al., 2016), which might hinder the complete decomposition and thus retain more material sources for humification. Interestingly, our results demonstrated that soil available K could hinder the formation/accumulation of HM, and increase the degree of humifications of humus, the mechanism of these phenomena was still need further investigation. For micro-elements, the increase in soil available $\mathrm{Fe}$ content were adverse to the accumulation of HA, high content of available $\mathrm{Zn}$ could promote the accumulation of FA but hinder the accumulation of HA, while high contents of available $\mathrm{Fe}$ and $\mathrm{Cu}$ would decrease the degree of humifications. As Fe and $\mathrm{Cu}$ were the important components of lignin peroxidase (LiP) and laccase (Lac), the increase of $\mathrm{Fe}$ and $\mathrm{Cu}$ contents might result in the excess secretion of LiP and Lac, and subsequently cause the excess mineralization of lignin and other substances and decrease the stability of humus. Zn was closely associated with the activity of LiP as well, however, its impacts on LiP were controlled by its concentration, thus its impacts on each humus component exhibited obvious dual nature (Singhal and Rathore, 2001).

Though the overall impacts of litter characteristics on humus were weaker than soil properties, some of the litter substrate quality indicators still exhibited obvious correlations with humus properties. In which, high litter accumulation would considerably accelerate the HA accumulation and increase the degree of humifications, while its influences on FA and HM were negligible. Based on this phenomenon, we speculated that the nitrogenous substance in litters might be preferentially used for compounding HA rather than FA and HM. In addition, the PLS-R results demonstrated that high litter $\mathrm{N}$ content would increase the accumulation of HM while Mn contents would hinder the accumulation of HA and FA. High litter $\mathrm{N}$ might also promote the humification processes by accelerating microbial activities, while Mn, as the key components of Mn-peroxidase (Trap et al., 2013), might lead to the complete mineralization of lignin, thus decline the supplement of material source of humus. To our surprise, poor litter $\mathrm{P}$ conditions (high $\mathrm{C} / \mathrm{P}$ and low $\mathrm{P}$ content) seemed to be more favorable to increase the degree of humifications, while it was totally different from the results obtained formerly in soil, the mechanism for this was still need further investigation. In contrast to the findings of Trap et al. (2013), we did not find the significant correlations between litter $\mathrm{C} / \mathrm{N}$ and humus properties. That might be on account of the alteration of litter $\mathrm{C} / \mathrm{N}$ during the decomposition, because the litter residues with given $\mathrm{C} / \mathrm{N}$ range tend to form different humus components (Tripolskaja et al., 2014).

\section{Negative dissimilation of humus in pure forests and possible remediation approaches}

In the tested pure forests, soil from L. principis-rupprechtii, $P$. armandii, P. simonii exhibited the trend of low accumulation of humus (Fig. 1), which was mainly caused by the poor microbial conditions in soil (In these soils, the lowest microbial biomass carbon contents were observed). In addition, the enzymatic and nutrient properties which were adverse to the formation and accumulations of humus were observed in these 3 types of soil. Such as low soil alkaline $\mathrm{N}$ contents, low soil phosphatase and dehydrogenase activity and high available Fe contents, and low soil available $\mathrm{P}$ content was observed in L. principis-rupprecbtii forest soil (Tables 2 and 3, Fig. 2). Furthermore, low litter accumulation, low litter $\mathrm{N}$ contents and high litter $\mathrm{Mn}$ contents were also responsible for the poor humus contents 
in P. simonii and L. principis-rupprecbtii forests soil (Table 1, Fig. 2). As to the humification characteristic, soil from P. orientalis, P. armandii and B. platyphylla exhibited a trend of low humufication degree (Fig. 1), which was mainly resulted from the lowest soil available $\mathrm{K}$ contents in these forest soils (Table 2, Fig. 2). In addition, low litter accumulation and high litter P content (especially in B. platyphylla forest) and high soil available Fe contents (especially in soil from $P$. armandii and B. platyphyll forests) would also hinder the increase in degree of humifications. These negative humus dissimilation phenomena should be artificially intervened to increase the accumulation and stability of humus.

As the main reasons causing negative humus dissimilation were the particular soil properties and the single litter source (or poor litter accumulation) in pure forests, consequently, in forestry practice, planting understory (shrub or herbaceous plant) or forming mixed forests might be a feasible way to gradually improve the microbial, enzymatic and nutrient conditions, and thus improve the humus properties (Li and Liu, 2013). In particular, leguminous forages and tree species which could cause positive humus dissimilation (such as R. pseudoacacia and Q. liaotungensis in this study) were recommended for mixed afforestation. For the forest soil showed serious degradation in humus properties, it was recommended to directly add plant litters into soil to control the alteration of soil properties and provide more organic matter source for humus (Luc et al., 2015; Luc et al., 2013). In addition, $\mathrm{N}$ and $\mathrm{P}$ fertilization and $\mathrm{K}$ fertilization were also the potential approaches for rapidly increasing the contents of humus and degree of humifications, respectively.

\section{CONCLUSIONS}

Relatively to the litter properties, the particular soil properties (or rather, the polarized soil properties) were the dominant factors of the humus dissimilation in the pure forests. Specifically, high soil microbial biomass carbon (MC), alkaline $\mathrm{N}$ and available $\mathrm{P}$ contents, soil phosphatase, dehydrogenase and urease activities, and litter accumulation played the important roles in the accumulation of humic acid, while high soil available Fe and litter Mn contents were opposite. High soil MC, alkaline N, available $\mathrm{Zn}$ and P contents, and dehydrogenase and phosphatase activities contributed to the fulvic acid accumulation, while the high litter Mn content were opposite. High soil MC and alkaline $\mathrm{N}$ contents, dehydrogenase and phosphatase activities and high litter $\mathrm{N}$ content were in favor of the accumulation of humin, while high soil available $\mathrm{K}$ and $\mathrm{Zn}$ contents and sucrase activity were opposite. High available K content, urease and peroxidase activities and litter accumulation and $\mathrm{C} / \mathrm{P}$ ratio were beneficial to the increasing of humification degree, while high soil available $\mathrm{Fe}$ and $\mathrm{Cu}$ contents, catalase activity and litter P content were opposite.

\section{ACKNOWLEDGMENTS}

This work was supported by the National Science Foundation of China (No. 31070630).

\section{Author contribution}

Xiaoxi Zhang conducted the experiments, analyzed the data and wrote the manuscript. Zengwen Liu and Xiaoxi Zhang designed the experiments. Xiao Liang and Xiaobo Liu participated in the laboratory experimentation.

\section{REFERENCES}

Abakumov, E. V., T. Cajthaml, J. Brus and J. Frouz. 2013. Humus accumulation, humification, and humic acid composition in soils of two post-mining chronosequences after coal mining. J. Soils Sed. 13(3): 491-500.

Andreetta, A., G. Cecchini, E. Bonifacio, R. Comolli, S. Vingiani and S. Carnicelli. 2016. Tree or soil? Factors influencing humus form differentiation in Italian forests. Geoderma. 264: 195-204.

Andreetta, A., R. Ciampalini, P. Moretti, S. Vingiani, G. Poggio, G. Matteucci, F. Tescari and S. Carnicelli. 2011. Forest humus forms as potential indicators of soil carbon storage in Mediterranean environments. Biol. Fertil. Soils. 47(1): 31-40.

Bao, S. 2000. Soil Agro-chemistrical Analysis, China Agriculture Press, Beijing.

Berg, B. and C. McClaugherty. 2014. Plant Litter, Springer-Verlag, Berlin Heidelberg.

Bödeker, I., K. E. Clemmensen, W. Boer, F. Martin, Å. Olson and B. D. Lindahl. 2014. Ectomycorrhizal Cortinarius species participate in enzymatic oxidation of humus in northern forest ecosystems. New Phytol. 203(1): 245-256.

Cerli, C., L. Celi, K. Kaiser, G. Guggenberger, M. Johansson, A. Cignetti and E. Zanini. 2008. Changes in humic substances along an age sequence of Norway spruce stands planted on former agricultural land. Organ. Geochem. 39: 1269-1280.

Dang, Y., S. Li and G. Wang. 2012. Distribution characteristics of humus fraction in soil profile for the typical regions in the Loess Plateau. Acta Ecol. Sin. 32(6): 1820-1829.

Descheemaeker, K., B. Muys, J. Nyssen, W. Sauwens, M. Haile, J. Poesen, D. Raes and J. Deckers. 2009. Humus form development during forest restoration in exclosures of the Tigray highlands, Northern Ethiopia. Restor. Ecol. 17(2): 280-289.

Dong, Y., Q. Zeng, S. An and H. Zhang. 2015. Effects of different forest types on soil active organic carbon and soil humus composition in the Loess Plateau. J. Soil Water Conserv. 29: 143-148.

Guan, S. 1986. Soil Enzyme and Research Technology, Agriculture Press, Beijing.

Guan, S. and S. Dou. 2006. Driving factors of the decomposition and transformation of soil organic matter. J. Anhui Agric. Sci. 34(10): 2203-2206.

Hansen, K., L. Vesterdal, I. K. Schmidt, P. Gundersen, L. Sevel, A. Bastrup-Birk, L. B. Pedersen and J. Bille-Hansen. 2009. Litterfall and nutrient return in five tree species in a common 
garden experiment. Forest. Ecol. Manage. 257(10): 2133-2144.

Hassett, J. E., D. R. Zak, C. B. Blackwood and K. S. Pregitzer. 2009. Are basidiomycete laccase gene abundance and composition related to reduced lignolytic activity under elevated atmospheric $\mathrm{NO}^{3-}$ deposition in a northern hardwood forest? Microb. Ecol. 57(4): 728-739.

He, G. 2002. Degeneration of soil fertility in pure Chinese fir succession. J. Zhejiang Forest. Coll. 19: 100-103.

Khaled, H. and H. A. Fawy. 2011. Effect of different levels of humic acids on the nutrient content, plant growth, and soil properties under conditions of salinity. Soil Water Res. 6(1): 21-29.

Labaz, B., B. Galka, A. Bogacz, J. Waroszewski and C. Kabala. 2014. Factors influencing humus forms and forest litter properties in the mid-mountains under temperate climate of Southwestern Poland. Geoderma. 230: 265-273.

Lauber, C. L., R. L. Sinsabaugh and D. R. Zak. 2009. Laccase gene composition and relative abundance in oak forest soil is not affected by short-term nitrogen fertilization. Microb. Ecol. 57(1): 50-57.

Li, G., L. Yang, Y. Wang, L. Zhao and W. Tang. 2015. Effects of severa1 microorganisms on humus formation in stalk decomposition of Dicranopteris dichotoma. Chin. J. Trop. Crops. 36(4): 719-723.

Li, Q. and Z. Liu. 2013. Effects of decomposed leaf litter mixtures from Platycladus orientalis and broadleaf tree species on soil properties. Scan. J. Forest. Res. 28(7): 642-650.

Li, X., C. Zhang and J. Cheng. 1992. Effect of different forest types on humus composition and humic acid properties of soil on the Loess plateau. Acta Pedol. Sin. 29: 64-72.

Liu, Z., C. Mi, Q. Li and K. Chen. 2010. Theory of soil polarization in planted pure forests and its application in Loess Plateau of China. In: International Conference on Combating Land Degradation and Annual Councilor Meeting of WASWAC.

Liu, Z., E. Duan, Z. Liu and S. Feng. 2009. Soil polarization under pure stands of different tree varieties in semi-arid hilly areas of the loess plateau. Acta Pedol. Sin. 46(6): 1110-1120.

Luc, N. T., Z. Liu, X. Zhang, Y. Bing and B. Zhu. 2013. Using forage litter to improve soil degradation of pure Betula platyphylla forest in the Loess Plateau, China. Forest. Stud. 59(1): 5-12.

Luc, N. T., Z. Liu, Y. Bing, X. Zhang and T. H. Nguyen. 2015. The control of soil polarization in Populus simonii and Quercus liaotungensis forests by forage litter on the Loess Plateau, PR China. J. Forest. Res. 26(3): 687-695.

Ma, Y., H. Luo, J. Song, J. Mo, C. Yang, Z. Li, K. Cai and Q. Yin. 2013. Relationships between humus chemical composition and soil factors in typical tobacco growing regions in China. Acta Tabacaria Sin. 19: 21-25.

Mi, C., Z. Li and B. Zhu. 2015. Effect of litter decomposition on soil polarization in two typical planted pure broadleaved forests in the gully region of Loess Plateau, China. Nat. Environ. Poll. Technol. 14(2): 325-332.

Mi, C., Z. Liu, Q. Li and O. A. Mohamad. 2013. Effect of litter decomposition on soil polarization in three typical planted pure coniferous forests in Loess Plateau, China. Int. J. Agric. Biol. 15: 687-693.

Ni, X., W. Yang, B. Tan, H. Li, J. He, L. Xu and F. Wu. 2016. Forest gaps slow the sequestration of soil organic matter: A humification experiment with six foliar litters in an alpine forest. Sci. Rep. 6: e19744.

Paul, S. 2002. Humus: Still A Mystery, Northeast Organic Farming Association, New York.

Podrázský, V., J. Remeš, V. Hart and W. K. Moser. 2009. Production and humus form development in forest stands established on agricultural lands - Kostelec nad Černými lesy region. J. Forest. Sci. 55: 299-305.

Prescott, C. E. 2010. Litter decomposition: What controls it and how can we alter it to sequester more carbon in forest soils? Biogeochemistry. 101: 133-149.

Pshenichnikov, B. F. and N. F. Pshenichnikova. 2015. The impact of vegetation on humus formation and morphology of brown forest soils in coastal areas of the southeastern part of Russian far east. Eurasian Soil Sci. 48(4): 337-346.

Rinkes, Z. L., I. Bertrand, B. A. Z. Amin, A. S. Grandy, K. Wickings and M. N. Weintraub. 2016. Nitrogen alters microbial enzyme dynamics but not lignin chemistry during maize decomposition. Biogeochemistry. 128(1-2): 171-186.

Schaeffer, A., P. Nannipieri, M. Kästner, B. Schmidt and J. Botterweck. 2015. From humic substances to soil organic matter-microbial contributions. In: Honour of Konrad Haider and James P. Martin for their outstanding research contribution to soil science. J. Soils Sed. 15(9): 1865-1881.

Singhal, V. and V. Rathore. 2001. Effects of $\mathrm{Zn}^{2+}$ and $\mathrm{Cu}^{2+}$ on growth, lignin degradation and ligninolytic enzymes in Phanerochaete chrysosporium. World J. Microbiol. Biotechnol. 17(3): 235-240.

Trap, J., F. Bureau, G. Perez and M. Aubert. 2013. PLS-regressions highlight litter quality as the major predictor of humus form shift along forest maturation. Soil Biol. Biochem. 57: 969-971.

Tripolskaja, L., D. Romanovskaja, A. Slepetiene, A. Razukas and G. Sidlauskas. 2014. Effect of the chemical composition of green manure crops on humus formation in a soddy-podzolic soil. Eurasian Soil Sci. 47(4): 310-318.

Tu, L. H., H. L. Hu, G. Chen, Y. Peng, Y. L. Xiao, T. X. Hu and Y. Tang. 2014. Nitrogen addition significantly affects forest litter decomposition under high levels of ambient nitrogen deposition. PloS One. 9(2): e88752.

Wang, R., X. Kang, G. Quan and J. Zhang. 2015. Influence of Lantana camara on soil II. Effects of Lantana camara leaf litter on plants and soil properties. Allelopathy J. 35(2): 207-216.

Yan, D. 1997. Study on humus soil properties and soil enzyme activity of artificial forest. Forest. Sci. Tech. 22: 12-14.

Yu, J., C. Zhu, P. Guo and Y. Zhao. 2011. Effect of bio-active humic substance on the biomass of Glycyrrhiza uralensis, soil humus composition and enzymatic activities. Acta Agrestia Sin. 19(1): 68-74. 